\title{
Does School Choice Lead to Sorting? Evidence from Tiebout Variation
}

\author{
By Miguel Urquiola*
}

Two issues dominate the school choice debate: whether competition would make schools more productive, and whether choice would result in sorting or stratification. In trying to answer these questions, economists have generally focused on the consequences of voucher systems, yet inter-district or Tiebout choice is, and is likely to remain, the main form of school choice in the United States. Surprisingly, we know comparatively little about its effects.

This paper focuses on whether inter-district choice leads to sorting, an issue on which there is no consensus. In recent work, for instance, Charles T. Clotfelter (1999) argues that district availability does influence children's peer groups, but Alberto Alesina et al. (2002) suggest this finding reflects a failure to consider within-district sorting via attendance areas.

The issue is difficult to settle because district concentration may be correlated with unobserved factors that affect outcomes of interest. To address this problem, this study uses a research design that builds from an Alesina and Enrico Spolaore (1997)-type model. It starts with the observation that metropolitan areas in fact contain two education markets, one at the primary and one at the secondary level, and that these often contain different numbers of districts. It is natural to motivate such differences as reflecting the presence of higher fixed costs at the secondary level, and the paper presents substantial prima facie evidence consistent with this possibility.

\footnotetext{
* School of International and Public Affairs and Department of Economics, Columbia University, 1402B International Affairs Building, New York, NY 10027 (e-mail: msu2101@columbia.edu). For generous feedback, I am indebted to Timothy Besley, David Card, Kenneth Chay, Stephen Coate, Chang-Tai Hsieh, Darren Lubotsky, Randall Reback, Jesse Rothstein, David Stern, and three anonymous referees. Earlier versions of this paper circulated as "Demand Matters: School District Concentration, Composition, and Educational Expenditure," and "School Choice and School Productivity: What Can Tiebout Really Reveal?"
}

Differences in the number of primary and secondary districts make it possible to identify the effects of changes in district availability using between-level, within-area changes in district concentration. Two factors underlie this design's contribution: (a) the use of within-area variation allows significant controls for unobserved heterogeneity across markets; and (b) the approach takes advantage of education levelspecific data, which allows one to control for systematic and significant differences between the primary and secondary sectors. One must bear in mind, however, that both the presence and the magnitude of between-level differences are not randomly assigned, although these do seem to be significantly less correlated with observable metropolitan area (MA) characteristics than are measures of aggregate district concentration.

The results suggest that increases in district availability do affect children's district- and school-level peer groups (with respect to both race and parental education), and that they reduce private enrollment. Thus, district concentration seems to affect both the distribution and the composition of the students in the public sector. These findings are informative as regards some of the mechanisms that drive stratification in the United States. For instance, they are consistent with Steven G. Rivkin's (1994) finding that inter-district choice has limited the success of past racial integration efforts. Additionally, they are relevant to a variety of analyses that relate variation in school district availability to educational outcomes. ${ }^{1}$

The paper proceeds as follows. Section I discusses some background and introduces the research design, and Section II describes the data used. Section III presents results, and Section IV concludes.

\footnotetext{
${ }^{1}$ For instance, Dennis Epple and Richard E. Romano (2003) illustrate how sorting is relevant to a number of analyses of school choice, particularly if peer effects exist.
} 


\section{Background and Research Design}

In analyzing the effects of school choice, it is relevant to consider why households value the ability to select schools for their children. To the extent that parents choose schools based on their productivity, one might expect that school choice would improve school productivity substantially. On the other hand, Jesse Rothstein (2003) illustrates that parental concern for peer groups, if significant, might blunt these competitive effects.

The empirical literature does not reveal much about the extent to which choice leads to sorting. Most work focuses on comparing the outcomes of private and public schools, and assessing the impact of vouchers; its methodological emphasis is on approximating experimental conditions. ${ }^{2}$ By its very nature, such research is not informative as to sorting effects, since few children change schools as a result of the interventions studied.

Rather, to learn about the effects of school choice on sorting, one needs to look at situations in which there is substantial variation in the degree of choice observed across educational markets. ${ }^{3}$ Inter-district or Tiebout choice in the United States provides such an opportunity, since the number of school districts in metropolitan areas ranges from 1 to over 200.

Past work has not reached a consensus on whether district availability affects the peer groups children encounter at school. Clotfelter (1999) suggests that it does, but Alesina et al. (2000) and Caroline M. Hoxby (2000) argue this reflects a failure to consider withindistrict sorting via attendance areas; ${ }^{4}$ they conclude that it is these "jurisdictions" within jurisdictions, and not districts, that determine peer groups. ${ }^{5}$

\footnotetext{
${ }^{2}$ See Helen F. Ladd (2002), Derek Neal (2002), and Patrick J. McEwan (2004) for reviews of the literature on vouchers.

${ }^{3}$ For instance, Chang-Tai Hsieh and Urquiola (2003) consider Chile's nationwide voucher program, under which the private enrollment share ranges from 0 to about 60 percent across municipalities.

${ }^{4}$ These arise when a district operating many schools explicitly ties the attendance at a given school to a given residential area.

${ }^{5}$ In other work, Randall W. Eberts and Timothy J. Gronberg (1981) and Amy B. Schmidt (1992) present results
}

\section{A. A New Research Design}

In part, these disagreements reflect that district concentration may be endogenous. In order to deal with this complication, this paper notes that many MAs have more primary than secondary districts, which may reflect the presence of higher fixed costs at the secondary level. To motivate this, it follows Alesina and Spolaore (1997), modeling jurisdictional creation as a trade-off between the benefits of large jurisdictions and the costs of heterogeneity in large populations. $^{6}$

To illustrate their approach, consider an area, $m$, that has population, $Z$, and contains $T$ types of individuals. These individuals desire a public good, $g$, and the issue is how many local jurisdictions should be created for its provision. Individuals of different types are located at a distance $h$ from each other, where this captures heterogeneity; the greater $h$, the more different individuals are along a given dimension. Each type has a mass equal to $\Delta$, so $Z=\Delta T$. Each person has a utility function $U_{i}=g\left(A-\alpha l_{i}\right)+$ $y-t_{i}$, where $g>0, \alpha>0, A>0, y$ is income, and $t_{i}$ and $l_{i}$ are, respectively, the tax paid by individual $i$, and his distance from the public good.

In the case of education, the issue of interest is the number of school districts into which an area splits. In the model, one school and two borders characterize a district. The cost of each school is $k=\bar{k}+k_{1} S$, where $S$ is each district's population, and $\bar{k}$ and $k_{1}$ are fixed and variable costs, respectively. The social planner's solution is to locate the school in the middle of each district, and to create equally sized districts in the amount $N=(T / 2) \sqrt{(g \alpha h / \bar{k})}$. Indexing areas by $m$, this suggests a reduced form expression for district availability:

that, although generally consistent with the possibility that Tiebout choice leads to sorting, are not always significant. W. Norton Grubb (1982) studies whether districts become relatively more homogeneous over time. His results on income are consistent with this, but those on racial structure are not. For background on how district-based residential sorting has limited the effects of desegregation policies, see also Gary Orfield and Frank Monfort (1992) and Rivkin (1994).

${ }^{6}$ Alesina et al. (2000) similarly analyze the availability of local functional jurisdictions. 


$$
N_{m}=f\left(h_{m}, g_{m}, \alpha_{m}, \bar{k}_{m}\right) .
$$

The key predictions are: $(\partial N / \partial \bar{k})<0$, district availability decreases with the fixed costs incurred in setting up a district; and $(\partial N / \partial h)>0$, it increases with heterogeneity.

The emphasis on fixed costs is appropriate given evidence that is consistent with the existence of economies of scale in the school sector. For instance, Lawrence W. Kenny and Schmidt (1994) document that the number of school districts in the United States has dropped from 50,000 to 15,000 in the past decades, and a significant reason for this appears to be the exploitation of economies of scale. The second implication, that heterogeneity leads to greater demand for schools and districts, is relevant to the extent that households wish to separate themselves from households with different preferences and/or characteristics.

To build a research design, let MAs stand for the areas $m$, and note that in fact they contain two educational levels, which we can index $l=$ $p, s$, for primary and secondary, respectively. ${ }^{7}$ Note also that MAs often contain different numbers of districts at each level; for example, Santa Cruz, California, has 11 districts that operate primary schools, but only four that operate secondary ones.

To understand the origins of such differences, a first aspect to note is that primary and secondary schools in some sense have different technologies. Primary instruction is relatively simple and easy to replicate. A firstgrade teacher, for instance, can carry out most instruction in a single, simply equipped classroom. In contrast, secondary subjects like physics and athletics require specialized instructors and infrastructure, giving rise to higher fixed costs. This suggests that in equilibrium, primary schools should be smaller. Figure 1, panel A, shows that enrollment is an excellent predictor of school availability at the MA level and, as expected, the number of

\footnotetext{
${ }^{7}$ In this paper, the primary level will be understood as grades 1 to 8 (and ages 6 to 13), and the secondary level as grades 9 to 12 (and ages 14 to 18). This is also the official definition in many-though not all-states, an issue we return to below.
}

primary schools increases much faster with enrollment.

If fixed costs are higher at the secondary level, $\bar{k}_{s m}>\bar{k}_{p m}$, and if one thinks of these levels as distinct markets and allows for the existence of districts that specialize in one level, then one would expect that MAs will have more primary than secondary districts, $N_{p m}>N_{s m} \cdot 8$

As usual, things are more complicated than a model would suggest. Figure 2 shows two hypothetical MAs that are representative of the type of district structure observed in many MAs. Area A has four districts that operate at both education levels, i.e., they run both primary and secondary schools. Area B contains such districts as well (5 and 6), but also has five primary-only and two secondary-only districts. The primary-only districts will typically "feed" their students to the secondaryonly ones."

Despite these complications, Figure 1 shows that while enrollment does not predict district as well as school availability (panels $\mathrm{A}$ and $\mathrm{B}$ ), it is the case that among areas with between-level differences in district concentration, the number of primary districts increases faster with enrollment than the number of secondary districts (panel C). This within-area, between-level variation in district availability provides a strategy to study the effects of district concentration. For an example, consider a reduced-form regression of private enrollment, $P_{m}$ :

$$
P_{m}=\beta_{0}+\beta_{1} N_{m}+\beta_{2} X_{m}+\epsilon_{m}
$$

where $N_{m}$ is a measure of district concentration, and $X_{m}$ is a vector of MA characteristics. One might expect $\beta_{1}$ to be negative, since both productivity improvements and greater stratification mean that as their number increases, at least some districts become more attractive relative to the

\footnotetext{
${ }^{8}$ There is evidence that market participants do make distinctions between levels. For instance, Anthony S. Bryk et al. (1993) report that Catholic primary schools are generally smaller and run by parishes, while Catholic high schools are larger and typically administered by religious orders or archdioceses.

${ }^{9}$ In California, for instance, the name of each district indicates its type. Districts like 7 are called elementary, those like 10 are labeled union high school, and those like 5 are called unified.
} 
Panel A: Schools in all MAs

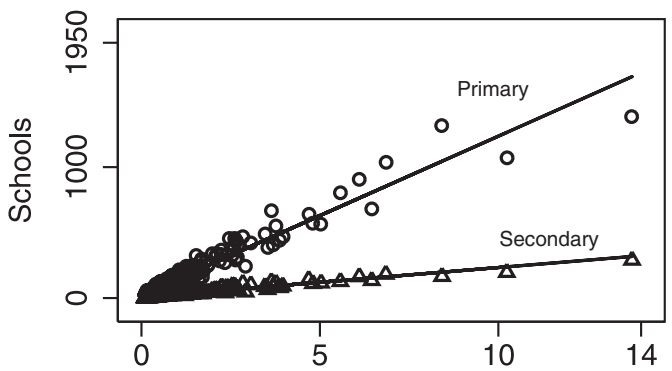

Total enrollment (hundreds of thousands)

Panel C: Districts in selected MAs (see note)

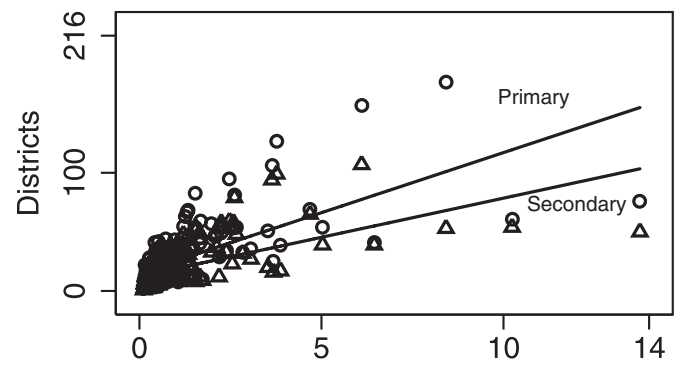

Total enrollment (in hundreds of thousands)
Panel B: Districts in all MAs

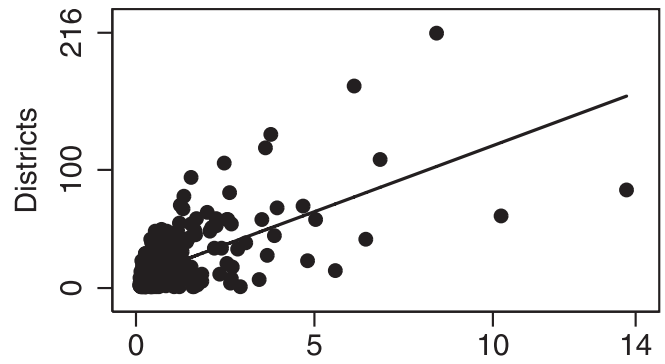

Total enrollment (hundreds of thousands)

Panel D: Ratio of primary to secondary dist.

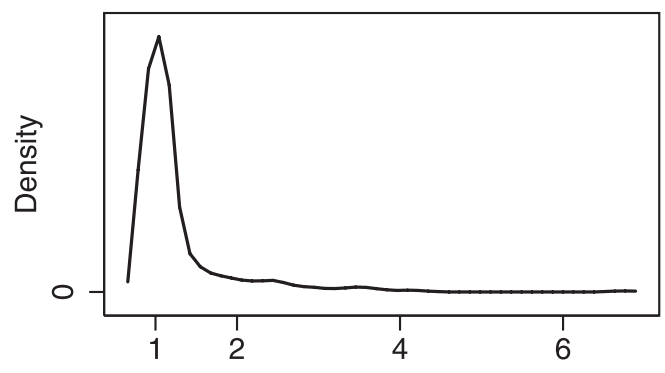

No. of primary/No. of secondary districts

Figure 1. School and School District Availability in MAs

Notes: These figures use the Common Core of Data (CCD) for 1990. In panels A, B, and C, the lines are predicted values of regressions of the number of schools and districts on enrollment. Panel $\mathrm{C}$ refers to MAs with different numbers of districts at the primary and secondary levels. Panel D plots the density of MA-level observations of the ratio of the total number of districts operating at the primary level to the total number of districts operating at the secondary level, for all MAs.

Area A

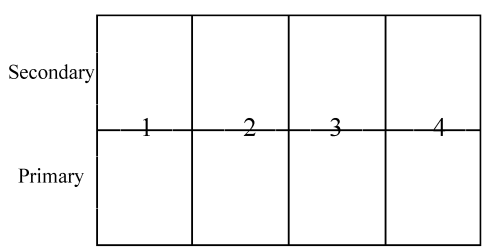

Area B

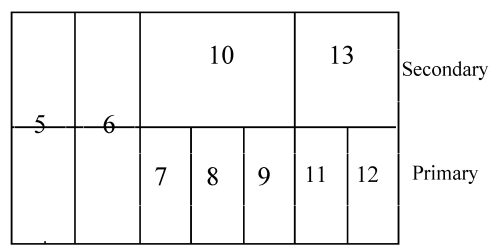

Figure 2. Hypothetical School District Structure

private sector. ${ }^{10}$ Nonetheless, cross-sectional estimates could be biased, for example, if there is

\footnotetext{
${ }^{10}$ Theoretically, though, the direction of the effect is not clear. One might expect that increased district availability would reduce private enrollment and perhaps raise public school expenditure, but as Epple and Romano (1996) and Thomas J. Nechyba (2003) illustrate, there are general equilibrium and potential feedback effects to consider.
}

variation in unobserved preferences for religious instruction. Some indication of this is found in the previous literature, which has produced mixed findings on whether district availability reduces private enrollment. $^{11}$

${ }^{11}$ For instance, Jorge Martinez-Vasquez and Bruce A. Seaman (1985) relate district concentration and private en- 
Using between-level differences in district concentration, however, one can introduce a dummy $Z_{m}$ for each MA, resulting in a fixed effects-type specification

$$
P_{l m}=\beta_{0}+\beta_{1} N_{l m}+\sum_{m=2}^{M} \beta_{m} Z_{m}+\epsilon_{l m} .
$$

This requires that both outcomes and district availability be measured with level-specific information, and has the advantage of controlling for MA characteristics, including those unobserved by the researcher, which are constant across levels.

\section{B. Sorting between and within Districts}

In short, the motivation is that by looking at MAs that have a different number of districts at each educational level, one can observe the behavior of the same set of households when it faces different opportunities to sort out. To clarify how such differential choice may arise, note that a household moving into an MA will typically find (often through information provided directly by realtors) that the purchase of a given residence entitles it to attend a given set of primary schools and a given set of secondary schools. In cases in which there are more districts at the primary level, households will find that conditional on settling in a given secondary district, they will be able to choose (via the choice of residence) between multiple primary districts. At such a juncture, they will potentially have a greater degree of influence over the peer groups their children encounter in the primary grades. 12

Alesina et al. (2000) emphasize that sorting can also occur within districts, via catchment areas. ${ }^{13}$ In fact, they suggest that it is the number of schools, rather than the number of dis-

rollment in 75 large MAs. They obtain mixed results, depending on the concentration measure. In contrast, Schmidt (1992) finds the expected relationship.

${ }^{12}$ At greater cost, households can of course also switch districts once they are in a given area.

${ }^{13}$ This type of sorting, which gives rise to "neighborhood schools," should be distinguished from the districtwide "open enrollment" policies that are in place in some districts. Epple and Romano (2003) contrast the implication of both types of choice. See also Randall Reback (2002) for an analysis of much less extended choice programs that tricts, that influences how homogeneous children's peer groups are. Although their analysis does not distinguish between education levels, this point is relevant because even households moving into a larger district that offers all grades will often find greater choice between schools at the primary level. This is because, as shown below, it is common for K-12 districts to contain a single high school and several primary schools. To the extent that the latter have separate catchment areas, families will again have a greater chance to select peer groups at the primary level. ${ }^{14}$ To account for this, the regressions below will include school availability measured at the relevant level.

\section{Possible Sources of Bias}

By exploiting within-MA, between-level differences in district availability, the strategy proposed here has the advantage of implicitly controlling for unobserved heterogeneity across MAs. This approach is not without potential limitations, however. A central one is that the presence and the magnitude of these differences may themselves be endogenous, and it is therefore relevant to discuss where they originate.

Table 1 contains descriptive statistics; Table 2, columns 1 and 2, present logit regressions that relate the presence of across-level differences in the number of districts to observable MA characteristics. A salient fact is that these are less likely to be observed in southern states, which partly reflects that the presence of such differences is frequently due to past institutional development. In southern states, county governments' responsibilities have historically included education (there are county-wide school districts), and there is no scope for specializing districts. In other states, the emergence of secondary-only districts seems to have been encouraged by tax limitations that made it difficult for single districts to fund complete $\mathrm{K}-12$ education

allow children to enroll in school districts different from those in which they live.

${ }^{14}$ Sandra E. Black (1999) shows that movements across catchment area borders are associated with discrete changes in housing prices. She attributes this to the capitalization of school quality, which can of course encompass peer group composition. 
TABle 1-Descriptive Statistics

\begin{tabular}{|c|c|c|c|c|c|c|c|c|c|}
\hline & \multicolumn{3}{|c|}{ School-level data } & \multicolumn{3}{|c|}{ District-level data } & \multicolumn{3}{|c|}{ MA-level data } \\
\hline & Mean & Std. dev. & $\mathrm{N}$ & Mean & Std. dev. & $\mathrm{N}$ & Mean & Std. dev. & $\mathrm{N}$ \\
\hline Racial heterogeneity ${ }^{\mathrm{a}}$ & 28.5 & 21.3 & 48,075 & 21.8 & 19.2 & 5,555 & 35.1 & 17.0 & 333 \\
\hline $\begin{array}{l}\text { Racial heterogeneity relative to } \\
\text { own MA }\end{array}$ & 69.4 & 55.8 & 48,075 & 55.9 & 47.1 & 5,555 & & & \\
\hline $\begin{array}{l}\text { Racial heterogeneity relative to } \\
\text { own district }\end{array}$ & 90.9 & 49.8 & 48,075 & & & & & & \\
\hline Educational heterogeneity ${ }^{\mathrm{a}}$ & & & & 66.0 & 9.5 & 5,554 & 72.1 & 2.4 & 318 \\
\hline $\begin{array}{l}\text { Educational heterogeneity } \\
\text { relative to MA }\end{array}$ & & & & 91.0 & 13.1 & 5,554 & & & \\
\hline Number of districts ${ }^{\mathrm{b}}$ & 43.4 & 46.6 & 51,518 & 50.5 & 49.2 & 5,555 & 18.8 & 24.3 & 333 \\
\hline Log of the number of districts & 3.2 & 0.6 & 51,518 & 3.48 & 1.00 & 5,555 & 2.3 & 1.2 & 333 \\
\hline $\begin{array}{l}\text { Number of districts operating } \\
\text { primary schools }\end{array}$ & & & & & & & 17.8 & 22.2 & 333 \\
\hline $\begin{array}{l}\text { Number of districts operating } \\
\text { secondary schools }\end{array}$ & & & & & & & 14.1 & 16.4 & 333 \\
\hline Number of primary schools & & & & 7.2 & 17.2 & 5,555 & 133.2 & 177.1 & 333 \\
\hline Number of secondary schools & & & & 1.5 & 3.3 & 5,555 & 28.4 & 33.3 & 333 \\
\hline $\begin{array}{l}\text { Proportion of hhlds. heads } \\
\text { with a college degree }\end{array}$ & 0.28 & 0.06 & 51,518 & 0.28 & 0.06 & 5,555 & 0.27 & 0.07 & 331 \\
\hline Proportion Catholic ${ }^{\mathrm{c}}$ & 0.21 & 0.11 & 51,518 & 0.23 & 0.12 & 5,555 & 0.21 & 0.12 & 333 \\
\hline Proportion poor & 0.12 & 0.04 & 51,518 & 0.12 & 0.04 & 5,555 & 0.13 & 0.05 & 333 \\
\hline Median income & 3.2 & 0.64 & 51,518 & 3.2 & 0.65 & 5,555 & 3.0 & 0.63 & 333 \\
\hline Proportion of hhlds. on welfare & 0.07 & 0.03 & 51,518 & 0.07 & 0.03 & 5,555 & 0.07 & 0.03 & 333 \\
\hline $\begin{array}{l}\text { Proportion of hhlds. that own } \\
\text { their home }\end{array}$ & 0.49 & 0.04 & 51,518 & 0.49 & 0.04 & 5,555 & 0.49 & 0.05 & 333 \\
\hline $\begin{array}{l}\text { Proportion of hhlds. } \\
\text { linguistically isolated }\end{array}$ & 0.04 & 0.05 & 51,518 & 0.04 & 0.05 & 5,555 & 0.03 & 0.04 & 333 \\
\hline
\end{tabular}

${ }^{a}$ This is the probability (in percentage terms) that two randomly selected individuals are from different racial or educational groups.

${ }^{\mathrm{b}}$ For MAs, the entries indicate the number of districts operating within the MA. For districts and schools, these are the corresponding figures for their respective districts or MAs.

${ }^{\mathrm{c}}$ The proportion Catholic is proxied using the proportion of individuals of French, French-Canadian, Irish, Italian, Polish, Portuguese, and Spanish ancestry. The proportion Hispanic enters as a separate control.

programs, particularly as initially low enrollment rates grew in the upper reaches of this range. ${ }^{15}$ Such limitations seem to have been more common in western states, and indeed column 1 suggests differences are more common in the West, as well as in the Northeast. ${ }^{16}$

Column 5 shows that among the MAs that do display between-level differences in district availability, the magnitude of these does not seem to be strongly correlated with observable MA traits. For instance, it is not significantly correlated with median income, the proportion

\footnotetext{
${ }^{15}$ See American Association of School Administrators Commission on District Reorganization (1958).

${ }^{16}$ For further illustration, Table A.1 in the Appendix presents a sample of real MAs, including areas like A and B (Figure 2), and describes the total number of districts operating at each level.
}

Catholic, population density, or poverty. On the other hand, it is significantly correlated with the proportion black (negatively) and the proportion Hispanic (positively). This is in contrast with the significantly stronger correlation that such observables display with the number of districts in an area, as described in column 6 . Columns 3 and 4 present similar evidence in regression form, showing that once one controls for their presence, the magnitude of betweenlevel differences (as measured by the ratio of the total number of primary to secondary districts in an MA) is not significantly higher in any given census region. This again is in contrast with what one observes concerning the number of districts.

Despite this evidence, between-level differences are of course not randomly assigned, and may additionally be related to unobservables. In 
Table 2-District-Availability and Between-Level Differences

\begin{tabular}{|c|c|c|c|c|c|c|}
\hline & \multicolumn{4}{|c|}{ Dependent variable } & \multicolumn{2}{|c|}{ Correlation coefficients } \\
\hline & \multicolumn{2}{|c|}{$\begin{array}{l}\text { Dummy for between- } \\
\text { level differences }\end{array}$} & \multirow{2}{*}{$\begin{array}{l}\text { Ratio of primar } \\
\text { to secondary } \\
\text { districts } \\
\text { (3) }\end{array}$} & \multirow{2}{*}{$\begin{array}{c}\text { No. of } \\
\text { districts } \\
\text { (4) }\end{array}$} & \multirow{2}{*}{$\begin{array}{l}\text { Ratio of primary } \\
\text { to secondary } \\
\text { districts } \\
\text { (5) }\end{array}$} & \multirow{2}{*}{$\begin{array}{c}\text { No. of } \\
\text { districts } \\
(6)\end{array}$} \\
\hline & (1) & (2) & & & & \\
\hline Census region: Northeast & $\begin{array}{l}0.8^{* * *} \\
(0.35)\end{array}$ & $\begin{array}{c}0.6 \\
(0.6)\end{array}$ & $\begin{array}{c}-0.1 \\
(0.1)\end{array}$ & $\begin{array}{c}3.2 \\
(4.8)\end{array}$ & & \\
\hline Census region: South & $\begin{array}{l}-1.1 * * * \\
(0.3)\end{array}$ & $\begin{array}{l}0.4 \\
(.5)\end{array}$ & $\begin{array}{c}0.1 \\
(0.1)\end{array}$ & $\begin{array}{l}-11.6^{* * * *} \\
(3.0)\end{array}$ & & \\
\hline Census region: West & $\begin{array}{l}0.7 * * \\
(0.4)\end{array}$ & $\begin{array}{l}0.7 \\
(0.5)\end{array}$ & $\begin{array}{c}0.2 \\
(0.1)\end{array}$ & $\begin{array}{l}-7.4^{* * *} \\
(2.8)\end{array}$ & & \\
\hline Percent pop. black & & $\begin{array}{l}-1.7 \\
(2.7)\end{array}$ & $\begin{array}{l}0.0 \\
(0.6)\end{array}$ & $\begin{array}{r}-12.0 \\
(15.7)\end{array}$ & $-0.18 * *$ & -0.00 \\
\hline Percent pop. Hispanic & & $\begin{array}{c}4.2 \\
(3.0)\end{array}$ & $\begin{array}{c}0.8 \\
(0.6)\end{array}$ & $\begin{array}{l}40.4^{* *} \\
(18.4)\end{array}$ & $0.17 * *$ & 0.05 \\
\hline Pct. hhlds. linguistically isolated & & $\begin{array}{r}-18.0 \\
(12.6)\end{array}$ & $\begin{array}{l}-5.4^{* * *} \\
(2.6)\end{array}$ & $\begin{array}{c}-166.9 * * \\
(67.0)\end{array}$ & 0.11 & $0.12 * *$ \\
\hline Percent adults with college degree & & $\begin{array}{c}1.1 \\
(3.7)\end{array}$ & $\begin{array}{c}0.2 \\
(0.9)\end{array}$ & $\begin{array}{c}14.7 \\
(17.7)\end{array}$ & 0.01 & $0.15 * * *$ \\
\hline Percent pop. Catholic & & $\begin{array}{c}0.2 \\
(2.0)\end{array}$ & $\begin{array}{c}0.2 \\
(0.4)\end{array}$ & $\begin{array}{c}10.4 \\
(13.0)\end{array}$ & -0.07 & $0.16^{* * *}$ \\
\hline Percent pop. poor & & $\begin{aligned}-10.0 \\
(8.1)\end{aligned}$ & $\begin{array}{l}-3.4 * * \\
(1.6)\end{array}$ & $\begin{array}{c}23.1 \\
(47.1)\end{array}$ & -0.03 & $-0.19 * * *$ \\
\hline Median income & & $\begin{array}{r}-0.0 \\
(0.0)\end{array}$ & $\begin{array}{c}-0.0 \\
(0.0)\end{array}$ & $\begin{array}{c}0.0 \\
(0.0)\end{array}$ & 0.08 & $0.33 * * *$ \\
\hline Percent hhlds. on welfare & & $\begin{array}{l}25.5^{* *} \\
(11.1)\end{array}$ & $\begin{array}{c}5.9 \\
(4.4)\end{array}$ & $\begin{array}{l}142.3^{* *} \\
(53.8)\end{array}$ & $0.21 *$ & 0.07 \\
\hline Pct. hhlds. that own their home & & $\begin{array}{c}-3.1 \\
(3.0)\end{array}$ & $\begin{array}{c}-0.7 \\
(0.5)\end{array}$ & $\begin{array}{l}30.5 \\
(21.7)\end{array}$ & -0.08 & -0.07 \\
\hline Population & & $\begin{array}{l}-1.3 * * * \\
(0.3)\end{array}$ & $\begin{array}{l}-0.2 * * * \\
(0.1)\end{array}$ & $\begin{array}{l}17.6 * * * \\
(3.7)\end{array}$ & -0.03 & $0.67 * * *$ \\
\hline Population density & & $\begin{array}{c}0.0 \\
(0.0)\end{array}$ & $\begin{array}{r}-0.0^{*} \\
(0.0)\end{array}$ & $\begin{array}{r}-0.0 \\
(0.0)\end{array}$ & -0.06 & $0.30 * * *$ \\
\hline Percent pop. immigrants & & $\begin{array}{l}7.5 \\
(6.9)\end{array}$ & $\begin{array}{l}4.8^{* *} \\
(1.8)\end{array}$ & $\begin{array}{c}-15.8 \\
(50.5)\end{array}$ & 0.22 & $0.26 * * *$ \\
\hline Number of districts & & $\begin{array}{l}0.1 * * * \\
(0.0)\end{array}$ & $\begin{array}{l}0.0^{* * *} \\
(0.0)\end{array}$ & & $0.14^{*}$ & \\
\hline $\begin{array}{l}\text { Dummy for MAs with } \\
\text { between-level differences }\end{array}$ & & & $\begin{array}{l}0.2 * * * \\
(0.1)\end{array}$ & & & \\
\hline$R^{2}$ & 0.102 & 0.340 & 0.390 & 0.566 & & \\
\hline $\mathrm{N}$ (districts) & 331 & 331 & 331 & 331 & 138 & 331 \\
\hline
\end{tabular}

Notes: *, **, and *** indicate significance at the 10-, 5-, and 1-percent level, respectively. Observations are at the MA level. Columns 1 and 2 are logit regressions, and columns 3 and 4 use OLS. Columns 5 and 6 present simple correlation coefficients.

particular, estimates from specifications like (3) might be biased if the correlation between unobserved characteristics and district concentration were to differ between levels. For example, households in a given MA might have a strong preference for private schooling (relative to households in other MAs) at the primary level, but a weaker relative preference at the secondary level.

A final issue is that the motivation above suggests that when between-level differences in district availability arise, this should be because there are more districts at the primary level. In fact, this is not always the case. While in the complete sample roughly 40 percent of MAs have more districts at the primary level, about 9 percent have more secondary districts. In the latter cases, however, the differences are significantly smaller. Specifically, among the 29 MAs with more secondary districts, the ratio of the total number of primary to secondary districts has an average of 0.91 (with a standard deviation of 0.05 and a minimum of 0.80 ). In con- 
trast, among the 138 MAs with more districts at the primary level, the mean value of this ratio is 1.65 (with a standard deviation of 0.85 and a maximum of 6.75). ${ }^{17}$ Figure 1, panel D, describes the cross-MA distribution of this ratio.

\section{Data and Measures}

This study uses two central data sources, the Common Core of Data (CCD) and the School District Data Book (SDDB), both for $1990 .^{18}$ The CCD, which is based mainly on administrative information, contains data on districts' location, their grade levels of operation, and various characteristics of their schools and students. The SDDB consists of district-level tabulations of the Census, with the key advantage that data for districts like 5 in Figure 2 can be extracted using appropriate age ranges. For instance, it is possible to determine how many children aged 6 to 13 - the standard primary age-attend private school. This procedure allows one not only to obtain level-specific data, but also to deal with the problem of geographic overlap posed by districts like 7 and 10 .

In view of this, the dependent variables for private enrollment were constructed using the SDDB. The dependent variables for sorting were created from the SDDB and CCD for district- and school-level analyses, respectively (the SDDB does not contain school information). ${ }^{19}$ The key independent variables, the measures of district and school availability, were constructed using the CCD.

The sorting analyses focus on stratification by racial and parental education groups. For race, the groups considered are: Asian, black, Hispanic, white, Native American, and other, and were constructed using data on students. For schooling, the groups are: no high school, high school degree, some college, and Bachelor's degree or higher,

\footnotetext{
${ }^{17}$ This reflects that differences in favor of the number of secondary districts mainly arise when there are one or two secondary-only districts operating alongside a much larger number of districts that operate at both levels. ScrantonWilkes Barre, Pennsylvania, for instance, has 33 districts that operate at both levels, and two that are secondary-only.

${ }^{18}$ The analyses based on the CCD were reproduced using 1999 data with no changes in the key conclusions.

${ }^{19}$ For many of the district-level analyses, it is possible to use the SDDB or the CCD data. The figures and regressions below occasionally use them interchangeably. Not surprisingly, the results are very similar.
}

and were constructed using data for household heads. The results use the heterogeneity measure in Alesina et al. (2002). For illustration, consider $r=1, \ldots, R$ racial groups, and let $S_{r m}$ be group $r$ 's share in the population of MA $m$. The basic heterogeneity measure used is $H_{m}=1-\sum_{r=1}^{R} S_{r m}^{2}$, and is interpreted as the probability that two individuals selected at random belong to two different racial groups. ${ }^{20}$

\section{Results}

Introducing the results on sorting, Figure 3 presents the distribution of this heterogeneity measure for race and parental education. Panels $\mathrm{A}$ and $\mathrm{B}$ show that among MAs, there is substantially more variation in racial than in educational heterogeneity, although as the descriptive statistics in Table 1 illustrate, there is less racial heterogeneity overall. The probability that two randomly selected people in an MA are from different racial groups has a mean of 0.35 and a standard deviation of 0.19 ; the average probability that they are from different educational groups is 0.72 , with a standard deviation of only 0.02 . Panels $\mathrm{C}$ and $\mathrm{D}$ present district-level distributions and show that much more sorting into districts occurs for race than for education. Moving from MAs to districts reduces the mean racial heterogeneity measure from 0.35 to 0.21 ; for education, the mean falls from 0.72 to 0.66 . Further, the coefficient of variation for parental schooling remains substantially lower.

\section{A. Sorting}

Table 3 presents regression evidence on the impact of district availability on district heterogeneity. For comparability with earlier work, it uses a relative sorting measure as the dependent variable, namely, the ratio between districts' heterogeneity measures and those of their respective MAs. ${ }^{21}$ This captures that a given

\footnotetext{
${ }^{20}$ One can also use the "exposure" measures described in Clotfelter (1999), which can be decomposed to determine the portions of stratification that are due to within- and between-district sorting. The qualitative conclusions these produce are similar to those presented below and are omitted for brevity.

21 The conclusions using absolute heterogeneity measures are quite similar and are omitted.
} 
Panel A: Race--Metropolitan areas

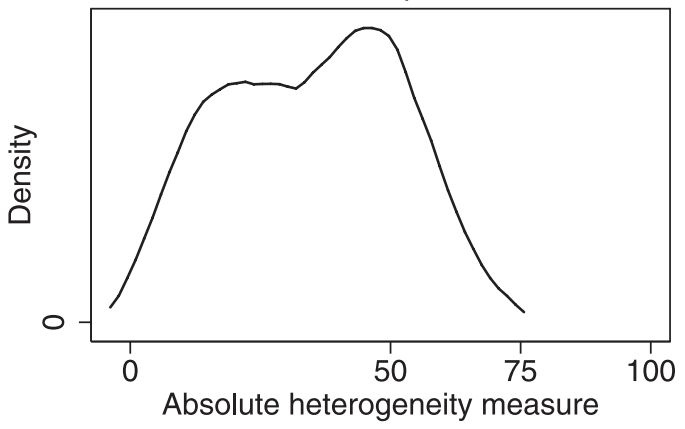

Panel C: Race--Districts

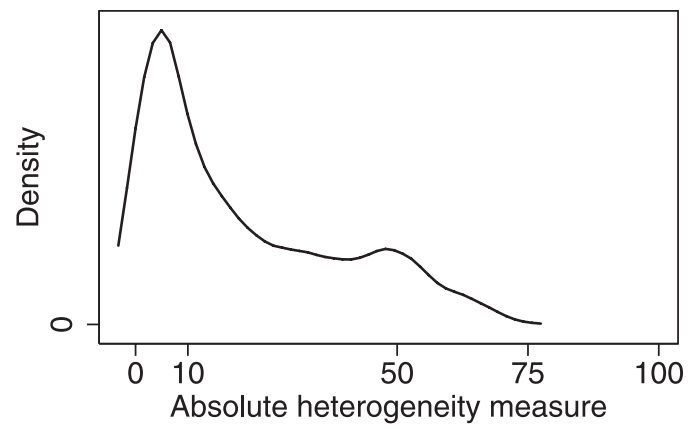

Panel B: Education--Metropolitan areas

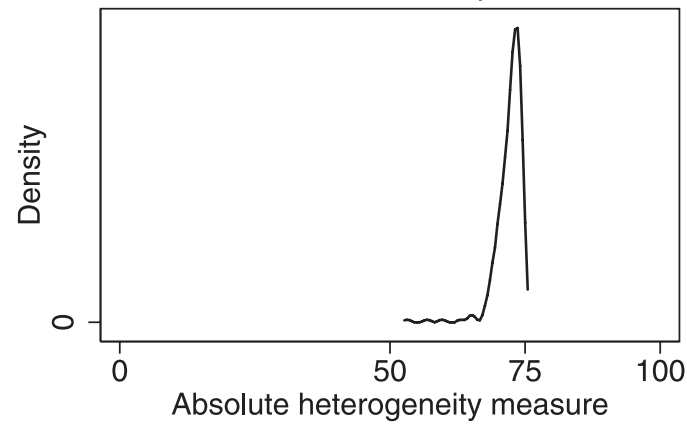

Panel D: Education--Districts

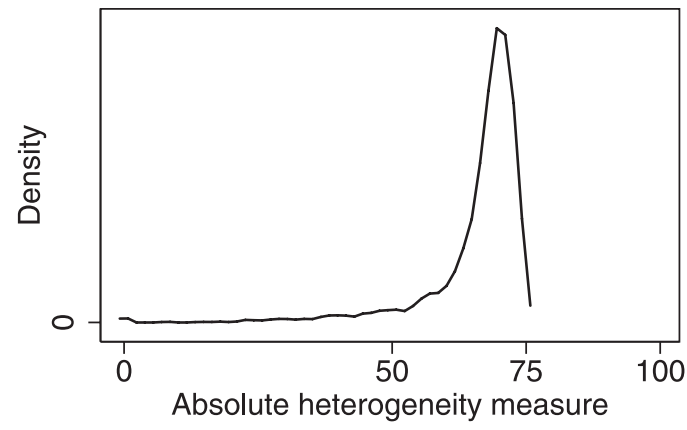

Figure 3. Heterogeneity AMONG MAs AND Districts

Notes: The graphs are densities of the absolute heterogeneity measure described in the data section. Panels A and B contain MA-level observations, and C and D are at the district level. All data are for 1990. Panels B and D use SDDB data, and Panels $A$ and $C$ use CCD school data aggregated up to the MA and district level, respectively. (Using SDDB data produces similar results.)

MA's heterogeneity limits that which can be displayed, on average, by its component districts. Further, for comparability with Alesina et al. (2002), the key independent variable is the $\log$ of the number of districts in the MA. ${ }^{22}$ All tables also include results using the absolute number of districts. ${ }^{23}$

Columns 1 and 2 present simple cross-sectional

\footnotetext{
${ }^{22}$ Alesina et al. do not discuss why they use this transformation, but it may be appropriate because of the nonlinearity in the relation between heterogeneity and district concentration. To illustrate, Figure A.1 in the Appendix shows that districts' (relative) heterogeneity is more negatively related to district availability when MAs have few districts. This is consistent with the possibility that parents care about peer groups along dimensions such as race and education, and that this is one of the first dimensions along which districts differentiate.

${ }^{23}$ Regressions using the number of districts per student yield similar results.
}

results. In panel $\mathrm{A}$, the simplest specification suggests that districts in areas with greater district availability are more racially homogeneous with respect to their MAs. The initial point estimates suggest that doubling the number of districts in a district's MA would move it about 15 percent of a standard deviation in the distribution of relative sorting. Nonetheless, the addition of controls (column 2) renders the key coefficient insignificant. This is consistent with earlier work.

Columns 3 to 5 use what we will label levelspecific data, which is necessary to implement the research design introduced above. Specifically, there are two observations for districts that operate at both levels. For example, an area like B in Figure 2 would supply seven observations at the primary level and four at the secondary level, with the district availability measures also calculated for each level. Column 5 includes MA dummies and 
Table 3-Does District Availability Affect District-Level Peer Groups?

(Dependent variable: Districts' heterogeneity relative to that in their MA)

\begin{tabular}{|c|c|c|c|c|c|}
\hline & \multicolumn{2}{|c|}{ Cross-sectional data } & \multicolumn{3}{|c|}{ Level-specific data } \\
\hline & (1) & (2) & (3) & (4) & (5) \\
\hline \multicolumn{6}{|l|}{ Panel A: Race } \\
\hline \multirow{2}{*}{ Log of the number of districts } & $-7.1 * * *$ & -1.9 & $-8.8 * * *$ & $-9.9 * * *$ & $-10.2 * * *$ \\
\hline & $\begin{array}{c}(1.1) \\
{[-0.15]}\end{array}$ & $\begin{array}{c}(3.0) \\
{[-0.04]}\end{array}$ & $\begin{array}{c}(1.1) \\
{[-0.19]}\end{array}$ & $\begin{array}{c}(1.9) \\
{[-0.21]}\end{array}$ & $\begin{array}{c}(2.7) \\
{[-0.22]}\end{array}$ \\
\hline$R^{2}$ & 0.023 & 0.070 & 0.030 & 0.049 & 0.164 \\
\hline Controls $^{\mathrm{a}}$ & $\mathrm{N}$ & Y & $\mathrm{N}$ & $\mathrm{Y}$ & $\mathrm{N}$ \\
\hline MA dummies & $\mathrm{N}$ & $\mathrm{N}$ & $\mathrm{N}$ & $\mathrm{N}$ & $\mathrm{Y}$ \\
\hline $\mathrm{N}$ (districts) & 5,555 & 5,555 & 9,452 & 9,452 & 9,452 \\
\hline MAs covered & 318 & 318 & 318 & 318 & 318 \\
\hline \multirow[t]{2}{*}{ Number of districts } & $\begin{array}{l}-0.11 * * * \\
(0.03)\end{array}$ & $\begin{array}{r}-0.02 \\
(0.06)\end{array}$ & $\begin{array}{l}-0.2 * * * \\
(0.0)\end{array}$ & $\begin{array}{l}-0.2 * * * \\
(0.1)\end{array}$ & $\begin{array}{c}-0.1^{*} \\
(0.1)\end{array}$ \\
\hline & {$[-0.11]$} & {$[-0.02]$} & {$[-0.21]$} & {$[-0.21]$} & {$[-0.10]$} \\
\hline$R^{2}$ & 0.014 & 0.071 & 0.019 & 0.042 & 0.162 \\
\hline Controls ${ }^{\mathrm{a}}$ & $\mathrm{N}$ & Y & $\mathrm{N}$ & Y & $\mathrm{N}$ \\
\hline MA dummies & $\mathrm{N}$ & $\mathrm{N}$ & $\mathrm{N}$ & $\mathrm{N}$ & Y \\
\hline $\mathrm{N}$ (districts) & 5,555 & 5,555 & 9,452 & 9,452 & 9,452 \\
\hline MAs covered & 318 & 318 & 318 & 318 & 318 \\
\hline \multicolumn{6}{|l|}{ Panel B: Education } \\
\hline \multirow[t]{2}{*}{ Log of the number of districts } & $\begin{array}{l}-2.1 * * * \\
(0.3)\end{array}$ & $\begin{array}{l}-2.9 * * * \\
(0.5)\end{array}$ & $\begin{array}{l}-2.1 * * * \\
(0.3)\end{array}$ & $\begin{array}{l}-2.6 * * * \\
(0.3)\end{array}$ & $\begin{array}{l}-6.3 * * * \\
(0.8)\end{array}$ \\
\hline & {$[-0.16]$} & {$[-0.22]$} & {$[-0.16]$} & {$[-0.19]$} & {$[-0.50]$} \\
\hline$R^{2}$ & 0.026 & 0.073 & 0.029 & 0.069 & 0.142 \\
\hline Controls $^{\mathrm{a}}$ & $\mathrm{N}$ & Y & $\mathrm{N}$ & $\mathrm{Y}$ & $\mathrm{N}$ \\
\hline MA dummies & $\mathrm{N}$ & $\mathrm{N}$ & $\mathrm{N}$ & $\mathrm{N}$ & $\mathrm{Y}$ \\
\hline $\mathrm{N}$ (districts) & 5,554 & 5,554 & 9,458 & 9,458 & 9,458 \\
\hline MAs covered & 318 & 318 & 318 & 318 & 318 \\
\hline \multirow[t]{3}{*}{ Number of districts } & $-0.03 * * *$ & $-0.08 * * *$ & $-0.05^{* * *}$ & $-0.09 * * *$ & $-0.08 * * *$ \\
\hline & $(0.01)$ & $(0.01)$ & $(0.01)$ & $(0.01)$ & $(0.03)$ \\
\hline & {$[-0.11]$} & {$[-0.26]$} & {$[-0.19]$} & {$[-0.34]$} & {$[-0.36]$} \\
\hline$R^{2}$ & 0.016 & 0.072 & 0.021 & 0.063 & 0.135 \\
\hline Controls $^{\mathrm{a}}$ & $\mathrm{N}$ & Y & $\mathrm{N}$ & $\mathrm{Y}$ & $\mathrm{N}$ \\
\hline MA dummies & $\mathrm{N}$ & $\mathrm{N}$ & $\mathrm{N}$ & $\mathrm{N}$ & $\mathrm{Y}$ \\
\hline $\mathrm{N}$ (districts) & 5,554 & 5,554 & 9,458 & 9,458 & 9,458 \\
\hline MAs covered & 318 & 318 & 318 & 318 & 318 \\
\hline
\end{tabular}

Notes: *, **, and *** indicate significance at the 10-, 5-, and 1-percent level, respectively. All regressions adjust for clustering at the MA level. The controls are the number of schools in districts' respective MAs, median income, a cubic of population, and the proportion of the population with college degree, Catholic, poor, on welfare, and linguistically isolated. The numbers in brackets indicate the proportion of a standard deviation change in the dependent variable induced by increasing the log of the number of districts by one, or increasing the number of districts by one standard deviation. The dependent variable is based on SDDB data, and the district availability measures come from the CCD.

${ }^{a}$ The regressions in column 5 contain one control variable that varies within MAs, across education levels: the number of schools operating at each level. Removing this variable has only a minmal effect on the coefficients of interest.

thus implements the full design-the effects of district availability are identified using only within-MA, between-level variation in district concentration. The results are now uniformly significant and somewhat larger in magnitude. Panel B presents similar results on the schooling of household heads. These sug- gest that, despite the fact that households are less sorted out on schooling than on race (Figure 3), increases in district availability are also associated with greater stratification along this characteristic.

To summarize, although there is no clear a priori expectation on the direction of bias, these 
regressions suggest that the cross-sectional coefficient on the effect of district availability on sorting is biased toward zero. The results using the full research design, which suggest that allelse-equal districts are more homogeneous where there are more of them, are in line with the usual expectation in the literature.

As indicated, there is more controversy on whether district availability also affects schoollevel peer groups. Clotfelter (1999) suggests that it does, but Hoxby (2000) finds that the racial heterogeneity of a student's peers is related to the number of schools, but not to the number of districts, in his or her MA, where the argument is that such sorting takes place within districts. One can consider this issue for race (although not for parental schooling), because the CCD provides information on schools' racial composition. ${ }^{24}$

As an introduction, Figure 4, panel A, shows that within-district sorting is indeed empirically relevant. The figure plots unweighted smoothed values of schools' heterogeneity relative to that of the district to which they belong, against the number of schools in their respective district, with a clear negative relation. Panel B plots schools' heterogeneity relative to their $M A$ against the number of schools in their MA, and shows a similar finding. ${ }^{25}$

The question at hand, however, is whether school-level heterogeneity is affected not only by school but also by district availability. Panel C presents evidence consistent with this. Here schools' heterogeneity (relative to their respective MAs) is related to the total number of districts in their respective MAs, and again there is a negative relation, although this does not control for the number of schools, or any other variable. The regression evidence is in Table 4, where the unit of observation is now the school. Columns 1 to 3 contain cross-sectional data. With these, the simplest specification does suggest that increased district availability makes schools more homogeneous. The addition of school availability as a control reduces the magnitude of the effect, but it is still negative and

\footnotetext{
${ }^{24}$ It is possible to construct level-specific school measures using information on schools' grades of operation.

${ }^{25}$ Both results are highly statistically significant in regression specifications.
}

significant. In column 3 , the addition of further controls renders them both insignificant.

Columns 4 to 6 again turn to level-specific data. $^{26}$ The coefficient on the district availability measure is now significant throughoutmost importantly in column 6, where the inclusion of MA dummies means that the effect is identified using within-MA, betweenlevel variation in district and school availability. Note also that the effect of school availability approaches zero and is no longer significant. This is to be expected given Figure 1, which shows that the number of schools in an MA is largely a function of its total enrollment. As this implies, there is much more variation (across MAs) in the ratio of primary to secondary districts than in the ratio of primary to secondary schools.

In short, these results suggest that district availability affects not only districts' composition but also the peer groups children encounter at school. One possible reason for this is that most districts simply do not have a large number of schools. Table A.2 in the Appendix shows that the median district (among those in MAs) has fewer than four schools. Among districts that operate primary schools, 50 percent have three or fewer. Among those that operate secondary schools, more than 70 percent have only one. This may, in turn, partially account for why many schools are simply not that much more racially homogeneous than their respective districts, as shown in Figure 4, panel D.

\section{B. Interpretation}

These results suggest that, on the margin, parents' choices regarding districts of residence do affect their children's peer groups. It is important to be clear, however, that the sorting effects identified may not be due solely to school choice, since they could also reflect the interaction between residential racial segregation patterns potentially unrelated to school choice, and the division of an urban area into jurisdictions tied to specific sets of schools.

\footnotetext{
26 The slight increase in sample sizes reflects that there are now two observations for schools that operate at both levels, almost always those that span K to 12 . As described below, such schools are rare.
} 

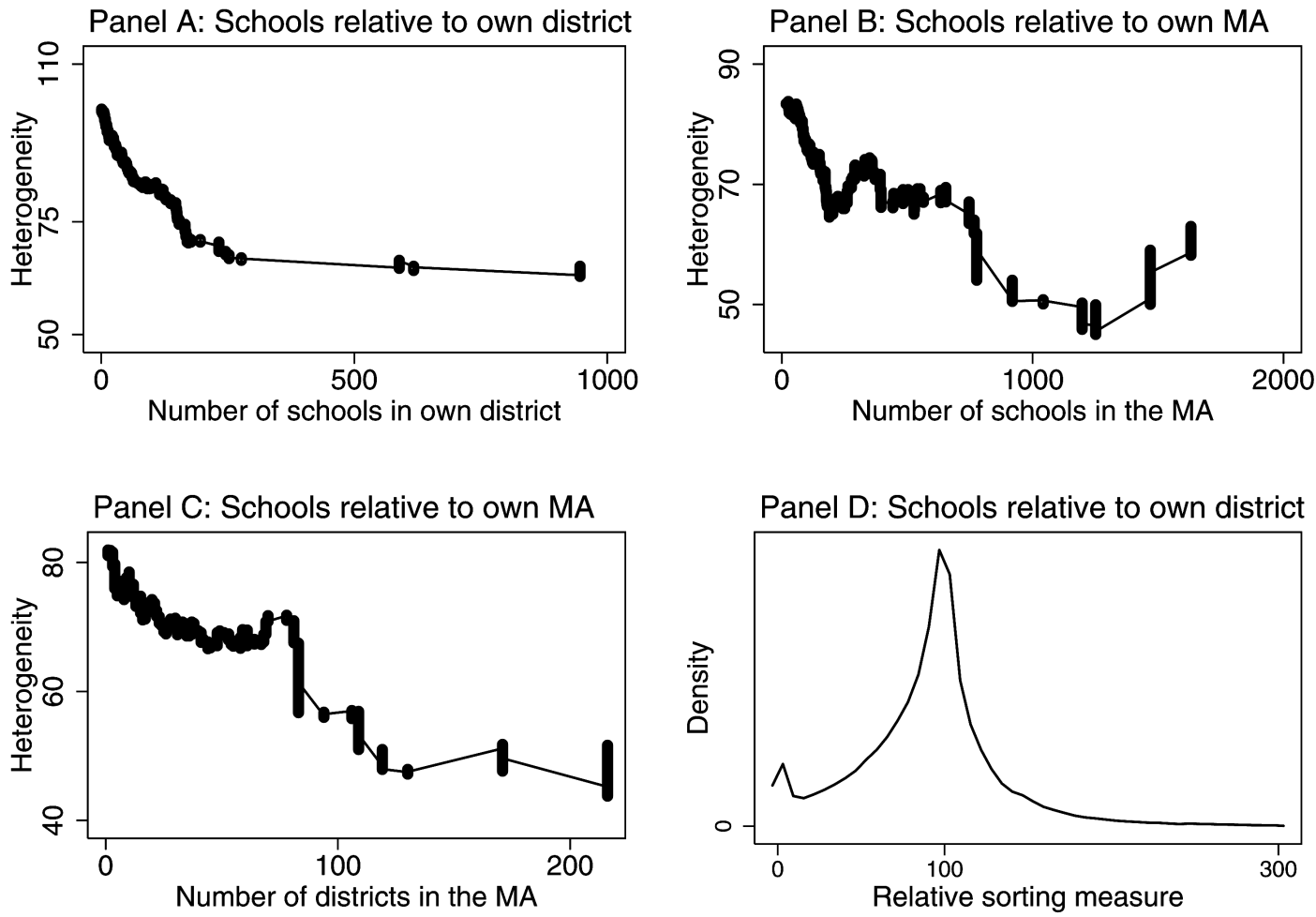

Figure 4. Racial Heterogeneity in Schools and MAs

Notes: Figures based on the CCD, 1990. Panels A to C plot unweighted smoothed values of schools' relative heterogeneity measures (with a bandwidth of 0.10 in all cases). Panel A uses schools' respective districts as the benchmark, and panels B and $\mathrm{C}$ use their respective MAs. Panel D describes the density of schools' heterogeneity relative to that observed in their respective districts.

To illustrate, assume that districts 7,8 , and 9 (in Figure 2) feed their students to district 10 , and that they share the same geographic area with it. What results like those in Table 3 tell us is that there is more segregation by race and parental schooling at the primary level (districts 7 to 9) than at the secondary level (district 10). One cannot rule out that this merely reflects that households in this area are spatially distributed in a certain way that happens to be associated with school district boundaries. $^{27}$

Nonetheless, it is likely that these results at least partially reflect parental preferences re-

${ }^{27}$ Because of such issues, disentangling the causes of sorting ultimately benefits from a general equilibrium approach. For an interesting example, see Patrick Bayer et al. (2004). garding school peer groups, for two reasons. First, as Table 4 shows, district boundaries also seem to affect the school-level (rather than just district-level) peer groups that students experience. Second, the next set of results shows that it also affects private enrollment. One would not expect these results (particularly the second), if the placement of district boundaries was orthogonal to factors that affect parents' choice of schools.

\section{Results on Private Enrollment}

As stated, the previous literature is not clear on whether increased district availability reduces private enrollment. To present evidence on this, Table 5 switches to MAs as the unit of analysis, since private enrollment rates are properly viewed as a market-level outcome. The table again begins with cross-sectional 
Table 4-Race: Does District Availability AfFect SChool-Level Peer Groups?

(Dependent variable: Schools' racial heterogeneity relative to their respective MAs)

\begin{tabular}{|c|c|c|c|c|c|c|}
\hline & \multicolumn{3}{|c|}{ Cross-sectional data } & \multicolumn{3}{|c|}{ Level-specific data } \\
\hline & (1) & (2) & (3) & (4) & (5) & (6) \\
\hline Log of the number of districts & $\begin{array}{c}-6.1^{* *} \\
(1.3) \\
{[-0.11]}\end{array}$ & $\begin{array}{c}-3.1^{* *} \\
(1.4) \\
{[-0.06]}\end{array}$ & $\begin{array}{c}-1.6 \\
(1.3) \\
{[-0.03]}\end{array}$ & $\begin{array}{c}-6.4 * * * \\
(1.3) \\
{[-0.11]}\end{array}$ & $\begin{array}{c}-5.3 * * * \\
(1.3) \\
{[-0.09]}\end{array}$ & $\begin{array}{c}-8.2 * * * \\
(1.6) \\
{[-0.15]}\end{array}$ \\
\hline Log of the number of schools & & $\begin{array}{c}-5.0 * * \\
(2.1)\end{array}$ & $\begin{array}{c}-10.5 \\
(3.5)\end{array}$ & & $\begin{array}{c}-1.7 \\
(1.3)\end{array}$ & $\begin{array}{l}0.6 \\
(0.6)\end{array}$ \\
\hline$R^{2}$ & 0.018 & 0.022 & 0.046 & 0.019 & 0.020 & 0.085 \\
\hline Controls & $\mathrm{N}$ & $\mathrm{N}$ & $\mathrm{Y}$ & $\mathrm{N}$ & $\mathrm{N}$ & $\mathrm{N}$ \\
\hline MA dummies & $\mathrm{N}$ & $\mathrm{N}$ & $\mathrm{N}$ & $\mathrm{N}$ & $\mathrm{N}$ & $\mathrm{Y}$ \\
\hline $\mathrm{N}$ (districts) & 48,075 & 48,075 & 48,075 & 50,224 & 50,224 & 50,224 \\
\hline MAs covered & 313 & 313 & 313 & 313 & 313 & 313 \\
\hline Number of districts & $\begin{array}{c}-0.2 * * * \\
(0.0) \\
{[-0.17]}\end{array}$ & $\begin{array}{c}-0.1 * * * \\
(0.0) \\
{[-0.08]}\end{array}$ & $\begin{array}{c}-0.0 \\
(0.0) \\
{[-0.04]}\end{array}$ & $\begin{array}{c}-0.2 * * * \\
(0.0) \\
{[-0.17]}\end{array}$ & $\begin{array}{c}-0.2 * * * \\
(0.1) \\
{[-0.17]}\end{array}$ & $\begin{array}{c}-0.1 * \\
(0.0) \\
{[-0.08]}\end{array}$ \\
\hline Number of schools & & $\begin{array}{c}-0.0 * * \\
(0.0)\end{array}$ & $\begin{array}{c}-0.0 \\
(0.0)\end{array}$ & & $\begin{array}{c}-0.0 \\
(0.0)\end{array}$ & $\begin{array}{c}0.0 \\
(0.0)\end{array}$ \\
\hline$R^{2}$ & 0.023 & 0.024 & 0.044 & 0.023 & 0.023 & 0.084 \\
\hline Controls & $\mathrm{N}$ & $\mathrm{N}$ & Y & $\mathrm{N}$ & $\mathrm{N}$ & $\mathrm{N}$ \\
\hline MA dummies & $\mathrm{N}$ & $\mathrm{N}$ & $\mathrm{N}$ & $\mathrm{N}$ & $\mathrm{N}$ & $\mathrm{Y}$ \\
\hline $\mathrm{N}$ (districts) & 48,075 & 48,075 & 48,075 & 50,224 & 50,224 & 50,224 \\
\hline MAs covered & 313 & 313 & 313 & 152 & 313 & 313 \\
\hline
\end{tabular}

Notes: * **, and *** indicate significance at the 10-, 5-, and 1-percent level, respectively. All regressions adjust for clustering at the MA level. The controls are median income, population, and the proportion of the population with college degree, Catholic, poor, on welfare, and linguistically isolated. The numbers in brackets indicate the proportion of a standard deviation change in the dependent variable induced by increasing the log of the number of districts by one, or increasing the number of districts by one standard deviation. All data come from the CCD for 1990 .

evidence: the dependent variable is the aggregate private enrollment rate in the MA, without distinguishing between educational levels, and the independent variable is based on the total number of districts in each MA. Column 1 shows that the cross-sectional evidence runs contrary to the usual expectation. Column 2 adds a number of controls, including the number of schools in the MA, rendering the coefficient on the number of districts insignificant.

Columns 3 to 6 use level-specific information: they incorporate two observations for each MA, one at each education level, with each regressed on a measure of the number of districts operating at the corresponding level. ${ }^{28}$ Columns 3 and 4 replicate the previous specifications, and again the coefficient on district

${ }^{28}$ That is, two measurements of private enrollment are calculated for each MA, one for children in the primary age range and one for children in the secondary range. The independent variable is based on the number of districts operating at the respective educational level. availability is not robust. In such analyses, however, one should control for the fact that, as Figure 5, panel A, shows, private enrollment is significantly higher at the primary level. In fact, panel B suggests that conditional on district availability, MAs display a roughly constant difference in private enrollment between these two levels. What may account for this difference? As discussed, average costs and therefore average tuition are higher at the secondary level. Additionally, other aspects of secondary education may lower parents' propensity to use private schools. For instance, in the secondary grades, schools intensify the separation of students into "tracks" (e.g., advanced placement versus vocational education). To the extent that these procedures separate students by socioeconomic characteristics, this may satisfy parental demand for sorting.

Regression 5 of Table 5 introduces a rough control for such factors by including a dummy for observations at the secondary level. Its coefficient is highly significant, and in results not presented here, is also very stable across re- 
Table 5-Does District Availability AfFect Private Enrollment Levels?

(Dependent variable: MA-level private enrollment rates)

\begin{tabular}{|c|c|c|c|c|c|c|}
\hline & \multicolumn{2}{|c|}{ Cross-sectional data } & \multicolumn{4}{|c|}{ Level-specific data } \\
\hline & (1) & (2) & (3) & (4) & $(5)$ & (6) \\
\hline Log of the number of districts & $\begin{array}{l}1.1 * * * \\
(0.2) \\
{[0.24]}\end{array}$ & $\begin{array}{c}-0.2 \\
(0.3) \\
{[-0.04]}\end{array}$ & $\begin{array}{l}1.3 * * * \\
(0.2) \\
{[0.28]}\end{array}$ & $\begin{array}{c}-0.9 * * * \\
(0.2) \\
{[-0.20]}\end{array}$ & $\begin{array}{c}-0.0 \\
(0.3) \\
{[-0.01]}\end{array}$ & $\begin{array}{c}-1.0^{* *} \\
(0.5) \\
{[-0.22]}\end{array}$ \\
\hline Log of the number of schools & & $\begin{array}{l}1.0 \\
(0.7)\end{array}$ & & $\begin{array}{l}3.7 * * * \\
(0.2)\end{array}$ & $\begin{array}{l}0.5 \\
(0.5)\end{array}$ & $\begin{array}{l}0.3 \\
(0.6)\end{array}$ \\
\hline Secondary level dummy & & & & & $\begin{array}{c}-5.8 * * * \\
(0.7)\end{array}$ & $\begin{array}{c}-6.3 \text { **** } \\
(0.9)\end{array}$ \\
\hline$R^{2}$ & 0.070 & 0.458 & 0.067 & 0.570 & 0.618 & 0.952 \\
\hline Controls & $\mathrm{N}$ & Y & $\mathrm{N}$ & Y & Y & $\mathrm{N}$ \\
\hline MA dummies & $\mathrm{N}$ & $\mathrm{N}$ & $\mathrm{N}$ & $\mathrm{N}$ & $\mathrm{N}$ & $\mathrm{Y}$ \\
\hline $\mathrm{N}$ & 291 & 291 & 582 & 582 & 582 & 582 \\
\hline MAs covered & 291 & 291 & 291 & 291 & 291 & 291 \\
\hline Number of districts & $\begin{array}{l}0.07 * * * \\
(0.01) \\
{[0.37]}\end{array}$ & $\begin{array}{c}0.02 \\
(0.02) \\
{[0.11]}\end{array}$ & $\begin{array}{l}0.09 * * * \\
(0.01) \\
{[0.38]}\end{array}$ & $\begin{array}{r}-0.02 \\
(0.02) \\
{[-0.09]}\end{array}$ & $\begin{array}{c}-0.0 \\
(0.0) \\
{[-0.01]}\end{array}$ & $\begin{array}{c}-0.03 * * \\
(0.01) \\
{[-0.13]}\end{array}$ \\
\hline Number of schools & & $\begin{array}{c}-0.02 * * \\
(0.01)\end{array}$ & & $\begin{array}{l}0.02 * * \\
(0.00)\end{array}$ & $\begin{array}{c}-0.0 \\
(0.0)\end{array}$ & $\begin{array}{c}0.00 \\
(0.0)\end{array}$ \\
\hline Secondary level dummy & & & & & $\begin{array}{c}-6.6^{* * * *} \\
(0.3)\end{array}$ & $\begin{array}{c}-6.4^{* * * *} \\
(0.2)\end{array}$ \\
\hline$R^{2}$ & 0.132 & 0.471 & 0.117 & 0.390 & 0.617 & 0.951 \\
\hline Controls & $\mathrm{N}$ & Y & $\mathrm{N}$ & $\mathrm{Y}$ & $\mathrm{Y}$ & $\mathrm{N}$ \\
\hline MA dummies & $\mathrm{N}$ & $\mathrm{N}$ & $\mathrm{N}$ & $\mathrm{N}$ & $\mathrm{N}$ & $\mathrm{Y}$ \\
\hline $\mathrm{N}$ & 291 & 291 & 582 & 582 & 582 & 582 \\
\hline MAs covered & 291 & 291 & 291 & 291 & 291 & 291 \\
\hline
\end{tabular}

Notes: *,**, and *** indicate significance at the 10-, 5-, and 1-percent level, respectively. The controls are median income, population, and the proportion of the population with college degree, Catholic, poor, on welfare, and linguistically isolated. The numbers in brackets indicate the proportion of a standard deviation change in the dependent variable induced by increasing the log of the number of districts by one, or increasing the number of districts by one standard deviation. The data on private enrollment come from the SDDB, and the data on district and school availability from the CCD.

gional samples. Further, its inclusion improves the fit significantly: the $R^{2}$ now exceeds 0.6 in both specifications. Finally, column 6 implements the full research design by adding a dummy for each MA, so that the effect of variations in district concentration is identified only using differences between levels, within MAs. This produces statistically significant results, which suggest that doubling the number of districts would reduce private enrollment by onefifth of a standard deviation. ${ }^{29}$

\footnotetext{
${ }^{29}$ If parents value school choice, another testable implication arises because one would expect that between-level differences in district concentration might be correlated with intercity migration patterns depending on the age of households' children. An analysis using the Census PUMS data for 106 MAs, however, did not provide evidence of this. This might reflect that other considerations (e.g., the employment outlook or weather) overwhelm the availability of school districts when households make decisions on where to live.
}

\section{Conclusion}

An important question in the school choice debate is whether greater choice would result in stratification that might adversely affect some children. Inter-district choice provides a fruitful setting to look at this issue, not least because it is probably the most prevalent form of school choice in the United States. This paper relies on within-MA, between-level variation in district structure to suggest that increased district availability indeed affects children's district and school-level peer groups, and that it reduces private enrollment; i.e., district concentration seems to affect both the distribution and the composition of the students in the public sector.

The empirical strategy used to produce these findings has the advantage of introducing substantial controls for MA-level heterogeneity and of using level-specific information. At the same 

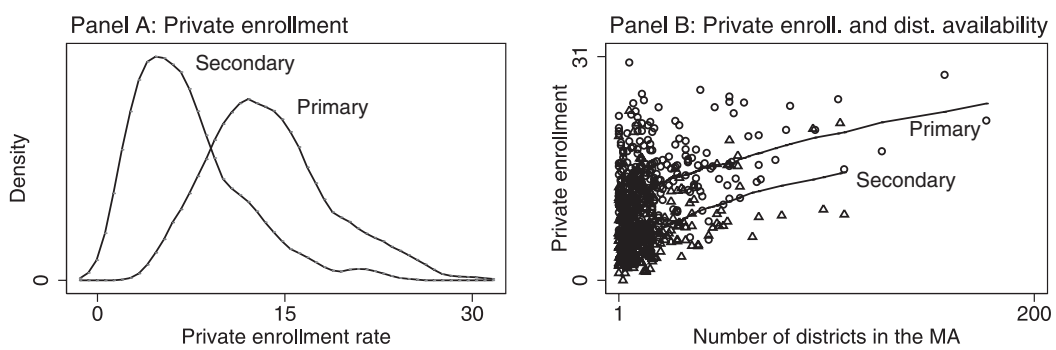

Figure 5. Primary and Secondary Private Enrollment Rates

Notes: Based on calculations using the SDDB and the CCD, both for 1990. Observations are at the MA level. Panel A contains densities of the private enrollment rate (in percentages). Panel B plots two observations for each MA-the primary and secondary private enrollment rates-both against the number of districts in the MA.

time, one must bear in mind that both the presence and the magnitude of between-level differences are not randomly assigned (although these do seem to be significantly less correlated with observable MA characteristics than are measures of aggregate district concentration). Aside from leaving open the potential for bias, this means that one cannot be certain that the introduction of additional districts, or of betweenlevel differences, would have similar effects elsewhere. Finally, note that the sorting identi- fied may not be due solely to school choice, since it could also reflect the interaction between residential segregation patterns (potentially unrelated to schooling) and school district boundaries.

Despite these caveats, these results are informative as to some of the mechanisms that drive stratification in the United States, and are relevant to a variety of analyses that relate variation in school district availability to educational outcomes.

\section{APPENDIX}

Table A.1-School Districts of Different Types in Selected MAs

\begin{tabular}{llcccccc}
\hline \hline Metropolitcan & State & $\begin{array}{c}\text { Primary only } \\
\text { districts } \\
\text { area }\end{array}$ & $\begin{array}{c}\text { Secondary only } \\
\text { districts } \\
(2)\end{array}$ & $\begin{array}{c}\text { Consolidated } \\
\text { districts } \\
(3)\end{array}$ & $\begin{array}{c}\text { Total } \\
\text { primary } \\
(4)\end{array}$ & $\begin{array}{c}\text { Total } \\
\text { secondary } \\
(5)\end{array}$ & $\begin{array}{c}\text { Ratio } \\
(4) /(5)\end{array}$ \\
\hline Kenosha & WI & 10 & 2 & 1 & 11 & 3 & 3.67 \\
Yuma & AZ & 7 & 2 & 0 & 7 & 2 & 3.50 \\
Portsmouth & NH-ME & 20 & 1 & 8 & 28 & 9 & 3.11 \\
Altantic City & NJ & 26 & 4 & 8 & 34 & 12 & 2.83 \\
Santa Cruz & CA & 8 & 1 & 3 & 11 & 4 & 2.75 \\
Joliet & IL & 26 & 6 & 8 & 34 & 14 & 2.43 \\
San Diego & CA & 27 & 5 & 12 & 39 & 17 & 2.29 \\
Burlington & VT & 12 & 2 & 6 & 18 & 8 & 2.25 \\
Victoria & TX & 2 & 0 & 2 & 4 & 2 & 2.00 \\
Nashville & TN & 3 & 0 & 8 & 11 & 8 & 1.36 \\
Vancouver & WA & 2 & 0 & 7 & 9 & 7 & 1.29 \\
Nassau-Suffolk & NY & 31 & 3 & 22 & 33 & 26 & 1.28 \\
Springfield & MA & 11 & 4 & 7 & 7 & 7 & 1.27 \\
Altoona & PA & 0 & 0 & 7 & 7 & 7 & 1.00 \\
Baltimore & MD & 0 & 0 & 1 & 1 & 1 & 1.00 \\
Bradenton & FL & 0 & 0 & 4 & 4 & 4 & 1.00 \\
Bristol & CT & 0 & 0 & 2 & 2 & 2 & 1.00 \\
Clarksville & TN-KY & 0 & 0 & & & & 79 \\
\hline
\end{tabular}


Table A.2-Distribution of School Districts by the Number of Schools They Contain

\begin{tabular}{lccc}
\hline \hline & \multicolumn{3}{c}{ Percentage of districts with $\leq$} \\
\cline { 2 - 4 } & Total & Primary & Secondary \\
\hline 1 school & 15.3 & 21.8 & 73.1 \\
2 schools & 28.8 & 38.3 & 85.1 \\
3 schools & 43.0 & 51.1 & 90.8 \\
4 schools & 53.7 & 61.2 & 93.6 \\
5 schools & 62.9 & 69.1 & 95.3 \\
$\ldots$ & & & 98.2 \\
10 schools & 83.0 & 85.3 & 98.3 \\
\hline
\end{tabular}

Notes: Based on CCD data for 1990. The columns that refer to primary and secondary include only districts with positive numbers of each type of school.
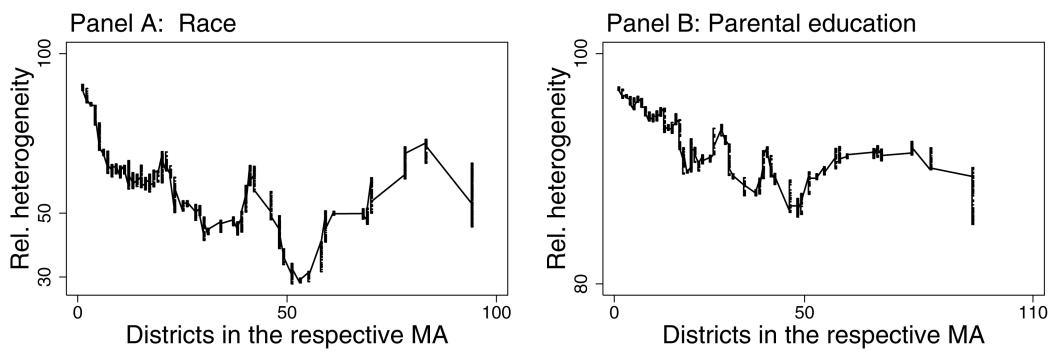

Figure A.1. District Availability and Districts' Relative Heterogeneity

Notes: Calculations based on the CCD, 1990. The lines plot unweighted smoothed values of districts' heterogeneity relative to that of their respective MAs (in both cases the bandwidth is equal to 0.05 ).

\section{REFERENCES}

Alesina, Alberto and Spolaore, Enrico. "On the Number and Size of Nations." Quarterly Journal of Economics, 1997, 112(4), pp. 1027-56.

Alesina, Alberto; Baqir, Reza and Hoxby, Caroline. "Political Jurisdictions in Heterogeneous Communities." National Bureau of Economic Research, Inc., NBER Working Papers: No. 7859, 2000.

American Association of School Administrators, Commission on School District Reorganization. School district organization. Washington, DC: American Association of School Administrators, 1958.

Bayer, Patrick; McMillan, Robert and Rueben, Kim. "Residential Segregation in General Equilibrium." National Bureau of Economic Research, Inc., NBER Working Papers: No. 11095, 2004.

Black, Sandra E. "Do Better Schools Matter? Parental Valuation of Elementary Education." Quarterly Journal of Economics, 1999, 114(2), pp. 577-99.

Bryk, Anthony S.; Lee, Valerie E. and Holland, Peter
B. Catholic schools and the common good. Cambridge, MA: Harvard University Press, 1993.

Clotfelter, Charles T. "Public School Segregation in Metropolitan Areas." Land Economics, 1999, 75(4), pp. 487-504.

Eberts, Randall W. and Gronberg, Timothy J. "Jurisdictional Homogeneity and the Tiebout Hypothesis." Journal of Urban Economics, 1981, 10(2), pp. 227-39.

Epple, Dennis and Romano, Richard E. "Ends against the Middle: Determining Public Service Provision when There Are Private Alternatives." Journal of Public Economics, 1996, 62(3), pp. 297-325.

Epple, Dennis and Romano, Richard. "Neighborhood Schools, Choice, and the Distribution of Educational Benefits," in Caroline M. Hoxby, ed., The economics of school choice. Chicago: University of Chicago Press, 2003.

Grubb, W. Norton. "The Dynamic Implications of the Tiebout Model: The Changing Composition of Boston Communities, 1960-1970." Public Finance Quarterly, 1982, 10(1), pp. 17-38.

Hoxby, Caroline M. "Does Competition among 
Public Schools Benefit Students and Taxpayers?" American Economic Review, 2000, 90(5), pp. 1209-38.

Hsieh, Chang-Tai and Urquiola, Miguel. "When Schools Compete, How Do They Compete? An Assessment of Chile's Nationwide School Voucher Program." National Bureau of Economic Research, Inc., NBER Working Papers: No. 10008, 2003.

Kenny, Lawrence W. and Schmidt, Amy B. "The Decline in the Number of School Districts in the U.S.: 1950-1980." Public Choice, 1994, 79(1-2), pp. 1-18.

Ladd, Helen F. "School Vouchers: A Critical View." Journal of Economic Perspectives, 2002, 16(4), pp. 3-24.

Martinez-Vasquez, Jorge and Seaman, Bruce A. "Private Schooling and the Tiebout Hypothesis." Public Finance Quarterly, 1985, 13(3), pp. 293-318.

McEwan, Patrick J. "The Potential Impact of Vouchers." Peabody Journal of Education, 2004, 79(3), pp. 57-80.

Neal, Derek. "How Vouchers Could Change the Market for Education." Journal of Economic Perspectives, 2002, 16(4), pp. 25-44.

Nechyba, Thomas J. "Centralization, Fiscal Federal- ism, and Private School Attendance." International Economic Review, 2003, 44(1), pp. 179204.

Orfield, Gary and Monfort, Frank. "Status of School Desecration: The Next Generation." Alexandria: Council of Urban Boards of Education, National School Boards Association, 1992.

Reback, Randall. "Capitalization under Public School Choice: Are the Winners Really the Losers?" National Center for the Study of Privatization in Education, Occasional Paper: No. 66, 2002.

Rivkin, Steven G. "Residential Segregation and School Integration." Sociology of Education, 1994, 67(4), pp. 279-92.

Rothstein, Jesse. "Good Principals or Good Peers? Parental Valuation of School Characteristics, Tiebout Equilibrium, and the Effects of Inter-District Competition." National Bureau of Economic Research, Inc., NBER Working Papers: No. 10666, 2004.

Schmidt, Amy B. "Private School Enrollment in Metropolitan Areas." Public Finance Quarterly, 1992, 20(3), pp. 298-320.

Tiebout, Charles M. "A Pure Theory of Local Expenditures." Journal of Political Economy, 1956, 64(5), pp. 416-24. 